\title{
Influence of chelated forms of trace elements on the live weight and livability of rearing stock of broilers
}

\author{
Elena Pilyukshina, ${ }^{1, *}$, Vladimir Khaustov ${ }^{1}$, Aleksandr Ozhimkov $^{2}$, Valentina Rusanova ${ }^{1}$, \\ Alexey Popelyaev ${ }^{1}$, and Ludmila Bondyreva ${ }^{1}$ \\ ${ }^{1}$ Altai State Agricultural University, 98, Krasnoarmejskij ave., Barnaul, 656049, Russia \\ ${ }^{2}$ Separate subdivision "Novosafonovskaya poultry farm" of Kuzbasskiy broiler LLC, ul. \\ Molodezhnaya, 2a, Novosafonovsky village, Kemerovo region, 653224, Russia
}

\begin{abstract}
Nowadays, organic forms of trace elements, which have a high bioavailability, and, as a consequence, have a beneficial effect on the body of animals and birds, are increasingly used in feeding. In this area, quite a lot of research has been carried out on the use of chelates in poultry feeding, but mainly for broiler chickens and laying hens. Therefore, the purpose of our study was the use of organic forms of trace elements such as iron, manganese, copper, zinc, and selenium in the diets of rearing stock of the parent flock of the ROSS cross. The experiment was carried out in the production conditions of the Novosafonovskaya poultry farm of Kuzbasskiy Broiler LLC and at the Small animal science department of the Altai State Agrarian University in 2020. The results of the experiment indicate that replacing $50 \%$ of the need for inorganic forms of iron, manganese, copper, zinc and selenium with organic analogs contributed to an increase in live weight, absolute and average daily gains of rearing stock. There was an increase in the uniformity of the flock in terms of live weight, both males and females. The crop percent of poultry in the experimental group was $3.2-4.6 \%$ higher due to a decrease not only in mortality, but also in culled chickens.
\end{abstract}

\section{Introduction}

Feeding is a key indicator influencing the growth and development of young birds. Nowadays, at a sufficiently high level of feeding, a search is underway for means to grow strong young birds, from which healthy offspring can be obtained in the future throughout the entire period of use.

Most studies on the inclusion of organic forms of trace elements were carried out on broiler chickens [1-6] and laying hens [7-9]. The positive effect of chelates on growth, development, productivity and product quality has been proven [10-14]. There are almost no studies on the inclusion of chelated forms of trace elements in the diets of rearing stock of broiler breeders, which is relevant.

\footnotetext{
*Corresponding author: lexx-74@bk.ru
} 


\section{Materials and Methods}

Therefore, the purpose of the study was the use of organic forms of trace elements such as iron, manganese, copper, zinc, and selenium in the diets of rearing stock of broiler breeders.

Experiments on the inclusion of chelated forms of trace elements in the composition of feed for rearing stock were carried out in the production conditions of a separate subdivision "Novosafonovskaya poultry farm" of Kuzbasskiy Broiler LLC and at the Small animal science department of the Altai State Agrarian University in 2020.

The object of the study was the rearing stock of the parent flock of the ROSS cross (hens and cockerels) from one day old to the age of 155 days, when they are transferred to the parent flock.

The subject of research is chelated forms of trace elements (iron, manganese, copper, zinc, selenium).

The experiment was carried out according to the scheme shown in Table 1.

Table 1. Scheme of the experiment.

\begin{tabular}{|l|l|}
\hline \multicolumn{1}{|c|}{ Group } & \multicolumn{1}{c|}{ Feeding features } \\
\hline control & The usual diet, incl. premix (100\% inorganic trace elements) \\
\hline experimental & $\begin{array}{l}\text { The usual diet, incl. premix (50\% inorganic trace elements }+50 \% \text { organic } \\
\text { trace elements) }\end{array}$ \\
\hline
\end{tabular}

Table 1 shows that the hens and cockerels of the control group received compound feed in accordance with the age of the bird with a standard premix containing all the necessary biologically active substances in accordance with the recommendations for growing the ROSS cross. In the experimental group, salts of such trace elements as iron, manganese, copper, zinc, and selenium were replaced by their organic analogs in the amount of $50 \%$ of their requirement for this trace element.

All other conditions of feeding and keeping were identical and corresponded to the zootechnical requirements and recommendations for keeping the ROSS cross.

During the experiment, the birds were weighed weekly. Based on these data, the uniformity of the herd, absolute and average daily gains were calculated.

The mortality and culling of birds with an indication of the reasons for leaving were carried out daily.

The research results were subjected to statistical data processing using Microsoft Excel software.

\section{Results}

Changes in feeding conditions are primarily reflected in live weight, which is a key indicator for rearing stock. The influence of chelated forms of trace elements on the live weight of hens is shown in Table 2.

The data in Table 2 indicate that, when tested, the hens of both groups were almost the same, weighed $39 \mathrm{~g}$, on average, and were slightly below normal (by $1 \mathrm{~g}$ or $2.5 \%$ ). In the future, starting from the first week, there is a tendency for more intensive growth of hens in the experimental group by $16-302 \mathrm{~g}$ or by $5.1-12.8 \%(\mathrm{p} \leq 0.001)$ compared to the control group. At the end of the experiment, i.e. when transferred to the parent flock, the average live weight of hens receiving chelated forms of microelements in their diet was $2996 \mathrm{~g}$, which is $6.8 \%$ more $(\mathrm{p} \leq 0.001)$ and $12.8 \%$ more than in the control group and the group recommended for the ROSS cross, respectively.

Comparing the live weight of the experimental bird with the one recommended for the ROSS cross, it can be concluded that throughout the entire study period, the hens from the experimental group exceeded the norm by $7.6-15.8 \%$, while they were only $4.0-12.0 \%$ in 
the control group, and even lagged behind in growth from the recommended by $0.1-4.0 \%$ in the period from 19 to 21 weeks.

Table 2. Live weight and uniformity of chicken flock.

\begin{tabular}{|c|c|c|c|c|c|}
\hline \multirow{2}{*}{$\begin{array}{c}\text { Age, } \\
\text { weeks }\end{array}$} & \multicolumn{3}{|c|}{ Live weight, g } & \multicolumn{2}{c|}{ Uniformity, \% } \\
\cline { 2 - 6 } & Norm & Control group & $\begin{array}{c}\text { Experimental } \\
\text { group }\end{array}$ & Control group & $\begin{array}{c}\text { Experimenta } \\
\text { group }\end{array}$ \\
\hline 0 & 40 & $39 \pm 0.3$ & $39 \pm 0.2$ & 69.2 & 70.2 \\
\hline 1 & 125 & $141 \pm 3.5$ & $157 \pm 3.1^{* * *}$ & 70.4 & 76.5 \\
\hline 2 & 240 & $263 \pm 4.8$ & $285 \pm 4.0^{* * *}$ & 56.4 & 66.8 \\
\hline 3 & 360 & $395 \pm 6.1$ & $426 \pm 5.9^{* * *}$ & 54.1 & 67.7 \\
\hline 4 & 480 & $533 \pm 7.2$ & $573 \pm 6.9^{* * *}$ & 54.2 & 64.8 \\
\hline 5 & 600 & $655 \pm 7.8$ & $723 \pm 7.1^{* * *}$ & 59.6 & 66.0 \\
\hline 6 & 740 & $776 \pm 8.3$ & $869 \pm 7.9^{* * *}$ & 68.4 & 70.6 \\
\hline 7 & 870 & $920 \pm 10.8$ & $999 \pm 11.3^{* * *}$ & 71.4 & 69.3 \\
\hline 8 & 990 & $1038 \pm 12.5$ & $1126 \pm 15.7^{* * *}$ & 72.7 & 67.7 \\
\hline 9 & 1100 & $1157 \pm 11.3$ & $1244 \pm 13.8^{* * *}$ & 77.2 & 68.8 \\
\hline 10 & 1200 & $1277 \pm 16.6$ & $1352 \pm 17.9^{* * *}$ & 77.4 & 73.3 \\
\hline 11 & 1300 & $1400 \pm 16.9$ & $1474 \pm 15.9^{* * *}$ & 76.5 & 83.3 \\
\hline 12 & 1400 & $1509 \pm 16.3$ & $1600 \pm 16.1^{* * *}$ & 77.3 & 82.5 \\
\hline 13 & 1505 & $1620 \pm 17.1$ & $1703 \pm 17.0^{* * *}$ & 79.6 & 80.7 \\
\hline 14 & 1610 & $1727 \pm 15.3$ & $1824 \pm 15.0^{* * *}$ & 80.2 & 84.9 \\
\hline 15 & 1715 & $1827 \pm 16.9$ & $1945 \pm 16.8^{* * *}$ & 80.0 & 87.2 \\
\hline 16 & 1825 & $1926 \pm 21.8$ & $2048 \pm 20.6^{* * *}$ & 76.0 & 84.9 \\
\hline 17 & 1945 & $2022 \pm 20.4$ & $2170 \pm 19.9^{* * *}$ & 79.6 & 83.5 \\
\hline 18 & 2070 & $2121 \pm 17.7$ & $2289 \pm 19.9^{* * *}$ & 81.5 & 79.7 \\
\hline 19 & 2200 & $2111 \pm 18.8$ & $2391 \pm 20.5^{* * *}$ & 79.0 & 71.0 \\
\hline 20 & 2340 & $2312 \pm 20.2$ & $2517 \pm 18.3^{* * *}$ & 73.0 & 79.0 \\
\hline 21 & 2495 & $2492 \pm 19,4$ & $2794 \pm 21.9^{* * *}$ & 75.0 & 70.0 \\
\hline 22 & 2655 & $2805 \pm 20.4$ & $2996 \pm 20.1^{* * *}$ & 81.0 & 83.0 \\
\hline $\begin{array}{c}\text { On } \\
\text { Overage }\end{array}$ & & & & 72.8 & 75.3 \\
\hline nnyyyy & & & & $8 \leq 0.01$ \\
\hline
\end{tabular}

- the difference in comparison with the control group is reliable: $*_{-} \mathrm{p} \leq 0.05, *^{*} *_{-} \mathrm{p} \leq 0.01, *^{* *}$ $\mathrm{p} \leq 0.001$

The uniformity in live weight characterizes the uniformity of the bird. The higher the uniformity, the higher the productivity, the easier it is to create optimal feeding and keeping conditions for most individuals, and the easier it is to work with such a herd $[15,16]$. Thus, the uniformity of hens in the control group ranged from $54.1-81.5 \%$, and in the experimental group - $64.8-87.2 \%$. On average, according to this indicator, the rearing stock in the experimental group exceeded their peers by $2.5 \%$, which indicates a positive effect of the inclusion of chelates of microelements in the feed on the chickens.

The change in the growth rate of the experimental bird is shown in Table 3.

The analysis of table 3 showed that the most intensive growth of rearing stock was observed before the 7th week of life at the level of 14.6-20.6 g of average daily gain in the control group and at the level of 18.3-21.0 $\mathrm{g}$ in the experimental group. Further, there was a moderate growth of hens up to 20 weeks of age. At the same time, the absolute increase in the control and experimental groups ranged from 90-123 g and 102-127 g, respectively. At the end of the experiment (at the age of 21-22 weeks), the absolute and average daily gains were maximum both in the control and in the experimental group. This tendency is typical for rearing stock and contributes to the correct development and formation of chickens.

The use of organic forms of trace elements contributed to the more intensive growth of chickens. Thus, the hens of the experimental group surpassed their peers in absolute and average daily gain by $191 \mathrm{~g}$ or $6.9 \%$ and by $1.2 \mathrm{~g}$ or $6.9 \%$, respectively. 
Table 3. Growth rate of hens.

\begin{tabular}{|c|c|c|c|c|}
\hline \multirow{2}{*}{ Age, weeks } & \multicolumn{2}{|c|}{ Absolute gain, g } & \multicolumn{2}{c|}{ Average daily gain, g } \\
\cline { 2 - 5 } & Control group & $\begin{array}{c}\text { Experimental } \\
\text { group }\end{array}$ & Control group & $\begin{array}{c}\text { Experimental } \\
\text { group }\end{array}$ \\
\hline 1 & 102 & 118 & 14.6 & 16.9 \\
\hline 2 & 122 & 128 & 17.4 & 18.3 \\
\hline 3 & 132 & 141 & 18.9 & 20.1 \\
\hline 4 & 138 & 147 & 19.7 & 21.0 \\
\hline 5 & 122 & 150 & 17.4 & 21.4 \\
\hline 6 & 121 & 146 & 17.3 & 20,9 \\
\hline 7 & 144 & 130 & 20.6 & 18.6 \\
\hline 8 & 118 & 127 & 16.9 & 18.1 \\
\hline 9 & 119 & 118 & 17.0 & 16.9 \\
\hline 10 & 120 & 108 & 17.1 & 15.4 \\
\hline 11 & 123 & 122 & 17.6 & 17.4 \\
\hline 12 & 109 & 126 & 15.6 & 18.0 \\
\hline 13 & 111 & 103 & 15.9 & 14.7 \\
\hline 14 & 107 & 121 & 15.3 & 17.3 \\
\hline 15 & 100 & 121 & 14.3 & 17.3 \\
\hline 16 & 99 & 103 & 14.1 & 14.7 \\
\hline 17 & 96 & 122 & 13.7 & 17.4 \\
\hline 18 & 99 & 119 & 14.1 & 17.0 \\
\hline 19 & 90 & 102 & 12.9 & 14.6 \\
\hline 20 & 101 & 126 & 14.4 & 18.0 \\
\hline 21 & 180 & 277 & 25.7 & 39.6 \\
\hline 22 & 313 & 202 & 44.7 & 28.9 \\
\hline Total & 2766 & 2957 & & 19.2 \\
\hline On average & & & 18.0 & \\
\hline
\end{tabular}

The dynamics of live weight and uniformity of a flock of cockerels under the influence of chelated forms of trace elements is presented in Table 4.

Analyzing table 4, we came to the conclusion that cockerels of the control group up to 7 weeks of age lagged behind by $0.2-4.4 \%$ in live weight, and then exceeded the recommended norm by $3.3-13.1 \%$. Throughout the study, cockerels from the experimental group had a live weight higher than the recommended one for the ROSS cross by 10.0$24.3 \%$, with the greatest relative difference observed in the first 10 weeks of life, which decreased with age.

The inclusion of chelates of trace elements in the diet of rearing cockerels contributed to an increase in the live weight of the bird by $3.9-27.2 \%$ in comparison with analogs from the control group. When transferred to the parent flock at 155 days of age, the cockerels of the experimental group exceeded the norm and their peers from the control group by $567 \mathrm{~g}$ or $17.0 \%$ and by $281 \mathrm{~g}$ or $7.7 \%$, respectively.

The use of organic trace elements in the feeding of rearing cockerels affected the uniformity of the flock. Thus, the uniformity of the flock of cockerels in the experimental group and at the end of the experiment was $85.0 \%$, while it was only $76.0 \%$ in the control group. At the same time, this indicator, on average for the entire period of the study, was higher in the experimental group by $6.1 \%$ compared to the control one.

For a more detailed assessment of the growth rate, the absolute and average daily gain of cockerels was calculated (Table 5). 
Table 4. Live weight and uniformity of a flock of cockerels.

\begin{tabular}{|c|c|c|c|c|c|}
\hline \multirow{2}{*}{$\begin{array}{c}\text { Age, } \\
\text { weeks }\end{array}$} & \multicolumn{3}{|c|}{ Live weight, g } & \multicolumn{2}{|c|}{ Uniformity, \% } \\
\cline { 2 - 6 } & Norm & Control group & $\begin{array}{c}\text { Experimental } \\
\text { group }\end{array}$ & Control group & $\begin{array}{c}\text { Experimental } \\
\text { group }\end{array}$ \\
\hline 0 & 40 & $40 \pm 0.3$ & $40 \pm 0.3$ & 85.0 & 84.7 \\
\hline 1 & 150 & $147 \pm 3.8$ & $165 \pm 3.6^{* * *}$ & 72.3 & 76.0 \\
\hline 2 & 310 & $360 \pm 5.1$ & $400 \pm 4.9^{* * *}$ & 67.6 & 70.5 \\
\hline 3 & 505 & $511 \pm 8.7$ & $649 \pm 8.3^{* * *}$ & 51.5 & 67.1 \\
\hline 4 & 720 & $698 \pm 9.2$ & $856 \pm 8.8^{* * *}$ & 50.7 & 54.2 \\
\hline 5 & 900 & $860 \pm 11.5$ & $1084 \pm 10.4^{* * *}$ & 46.4 & 54.2 \\
\hline 6 & 1075 & $1050 \pm 10.8$ & $1336 \pm 12.7^{* * *}$ & 61.4 & 53.3 \\
\hline 7 & 1230 & $1227 \pm 12.5$ & $1529 \pm 11.9^{* * *}$ & 64.8 & 61.5 \\
\hline 8 & 1375 & $1421 \pm 13.4$ & $1669 \pm 12.6^{* * *}$ & 66.6 & 58.8 \\
\hline 9 & 1510 & $1566 \pm 15.0$ & $1847 \pm 14.1^{* * *}$ & 62.7 & 67.8 \\
\hline 10 & 1640 & $1760 \pm 17.2$ & $2006 \pm 18.9^{* * *}$ & 66.6 & 72.8 \\
\hline 11 & 1770 & $1912 \pm 21.1$ & $2162 \pm 19.4^{* * *}$ & 71.6 & 76.9 \\
\hline 12 & 1900 & $2035 \pm 20.7$ & $2268 \pm 18.3^{* * *}$ & 69.9 & 78.6 \\
\hline 13 & 2030 & $2226 \pm 21.2$ & $2410 \pm 20.2^{* * *}$ & 73.3 & 72.4 \\
\hline 14 & 2160 & $2442 \pm 20.7$ & $2539 \pm 21.5^{* * *}$ & 63.5 & 84.2 \\
\hline 15 & 2290 & $2559 \pm 25.5$ & $2686 \pm 26.7^{* * *}$ & 70.9 & 75.4 \\
\hline 16 & 2430 & $2674 \pm 24.2$ & $2813 \pm 22.2^{* * *}$ & 72.6 & 80.5 \\
\hline 17 & 2575 & $2836 \pm 33.3$ & $2970 \pm 29.4^{* * *}$ & 59.4 & 79.6 \\
\hline 18 & 2725 & $2990 \pm 28.2$ & $3106 \pm 27.7^{* * *}$ & 71.7 & 74.3 \\
\hline 19 & 2880 & $3130 \pm 30.4$ & $3301 \pm 28.8^{* * *}$ & 66.0 & 73.3 \\
\hline 20 & 3035 & $3234 \pm 32.7$ & $3408 \pm 29.1^{* * *}$ & 65.0 & 73.0 \\
\hline 21 & 3195 & $3385 \pm 33.2$ & $3686 \pm 30.6^{* * *}$ & 65.0 & 75.0 \\
\hline 22 & 3345 & $3631 \pm 30.5$ & $3912 \pm 28.5^{* * *}$ & 76.0 & 85.0 \\
\hline On & & & & 66.1 & 72.2 \\
\hline average & & & & & \\
\hline-6 & & & & & \\
\hline
\end{tabular}

- the difference in comparison with the control group is reliable: ${ }^{*}$ - $\mathrm{p} \leq 0.05,{ }^{*}$ - $\mathrm{p} \leq 0.01,{ }^{* * *}-\mathrm{p} \leq 0.001$

Based on the data in Table 5, it can be concluded that the most intensive growth of cockerels in the control group was observed up to 8 weeks of life at the level of 21.6-30.4 g of average daily gain, and in the experimental group up to 7 weeks of age - at the level of 27, 6-35.6 g. Further, there was a slowdown in the growth of young birds in the experimental groups until 21-22 weeks of life, which is associated with the peculiarities of growing rearing stock.

On average, over the experiment, the cockerels of the control group were inferior to their counterparts from the experimental group, which were fed organic trace elements in the composition of compound feeds, in absolute and average daily gain by $281 \mathrm{~g}$ or $8.1 \%$ and $1.8 \mathrm{~g}$ or $8.1 \%$, respectively.

An important indicator when raising poultry is the livability of poultry, which determines the crop percent of young birds and, consequently, the number of parent flock. Fig. 1 shows the crop percent of hens, and Fig. 2 shows the crop percent of cockerels.

Fig. 1 shows that throughout the experiment, the crop percent of rearing stock of chickens in the experimental group, in which the bird received trace elements in organic form along with the feed, was $0.1-1.8 \%$ higher than in the control group. At the end of the experiment, the difference between the control and experimental groups for this indicator was $3.3 \%$ in favor of the experimental one. 
Table 5. Growth rate of cockerels.

\begin{tabular}{|c|c|c|c|c|}
\hline \multirow{2}{*}{$\begin{array}{l}\text { Age, } \\
\text { weeks }\end{array}$} & \multicolumn{2}{|c|}{ Absolute gain, $g$} & \multicolumn{2}{|c|}{ Average daily gain, $g$} \\
\hline & Control group & $\begin{array}{l}\text { Experimental } \\
\text { group }\end{array}$ & Control group & $\begin{array}{c}\text { Experimental } \\
\text { group }\end{array}$ \\
\hline 1 & 107 & 125 & 15.3 & 17.9 \\
\hline 2 & 213 & 235 & 30.4 & 33.6 \\
\hline 3 & 151 & 249 & 21.6 & 35.6 \\
\hline 4 & 187 & 207 & 26.7 & 29.6 \\
\hline 5 & 162 & 228 & 23.1 & 32.6 \\
\hline 6 & 190 & 252 & 27.1 & 36.0 \\
\hline 7 & 177 & 193 & 25.3 & 27.6 \\
\hline 8 & 194 & 140 & 27.7 & 20.0 \\
\hline 9 & 145 & 178 & 20.7 & 25.4 \\
\hline 10 & 194 & 159 & 27.7 & 22.7 \\
\hline 11 & 152 & 156 & 21.7 & 22.3 \\
\hline 12 & 123 & 106 & 17.6 & 15.1 \\
\hline 13 & 191 & 142 & 27.3 & 20.3 \\
\hline 14 & 216 & 129 & 30.9 & 18.4 \\
\hline 15 & 117 & 147 & 16.7 & 21.0 \\
\hline 16 & 115 & 127 & 16.4 & 18.1 \\
\hline 17 & 162 & 157 & 23.1 & 22.4 \\
\hline 18 & 154 & 136 & 22.0 & 19.4 \\
\hline 19 & 140 & 195 & 20.0 & 27.9 \\
\hline 20 & 104 & 107 & 14.9 & 15.3 \\
\hline 21 & 151 & 278 & 21.6 & 39.7 \\
\hline 22 & 246 & 226 & 35.1 & 32.3 \\
\hline Total & 3591 & 3872 & & \\
\hline $\begin{array}{c}\text { On } \\
\text { average }\end{array}$ & & & 23.3 & 25.1 \\
\hline
\end{tabular}

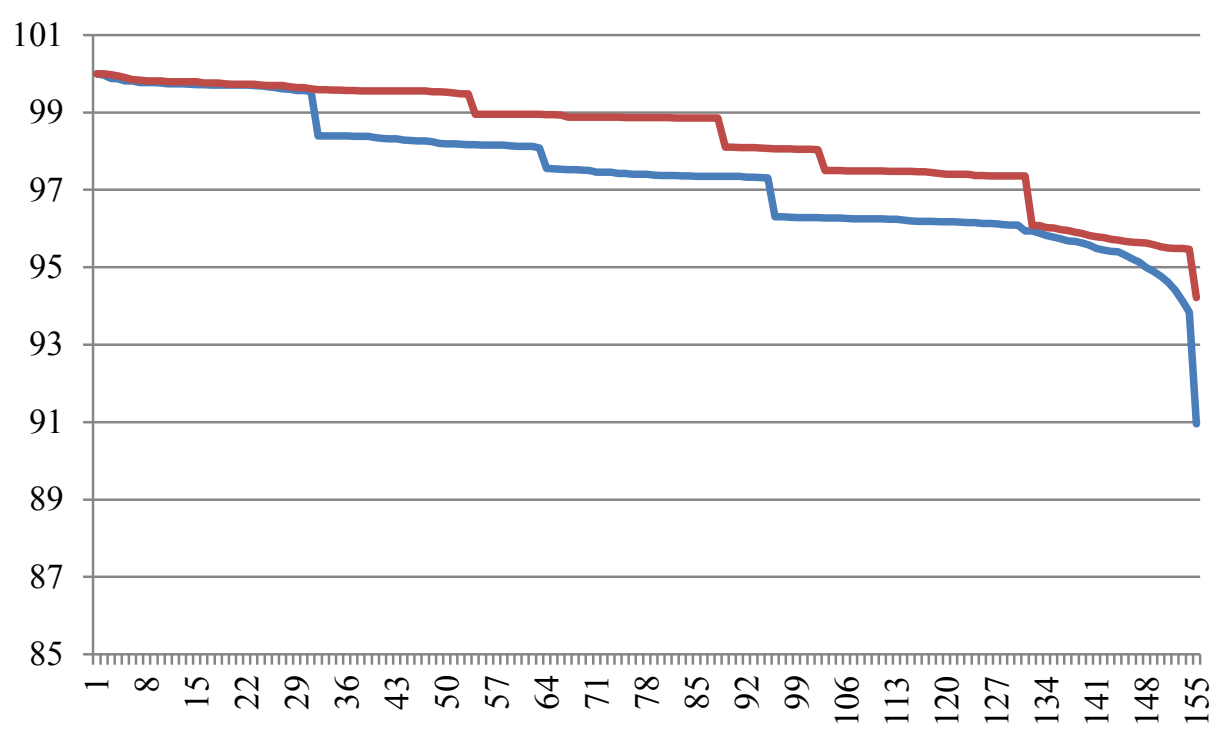

Fig. 1. Crop percent of hens by rearing periods, $\%$. 


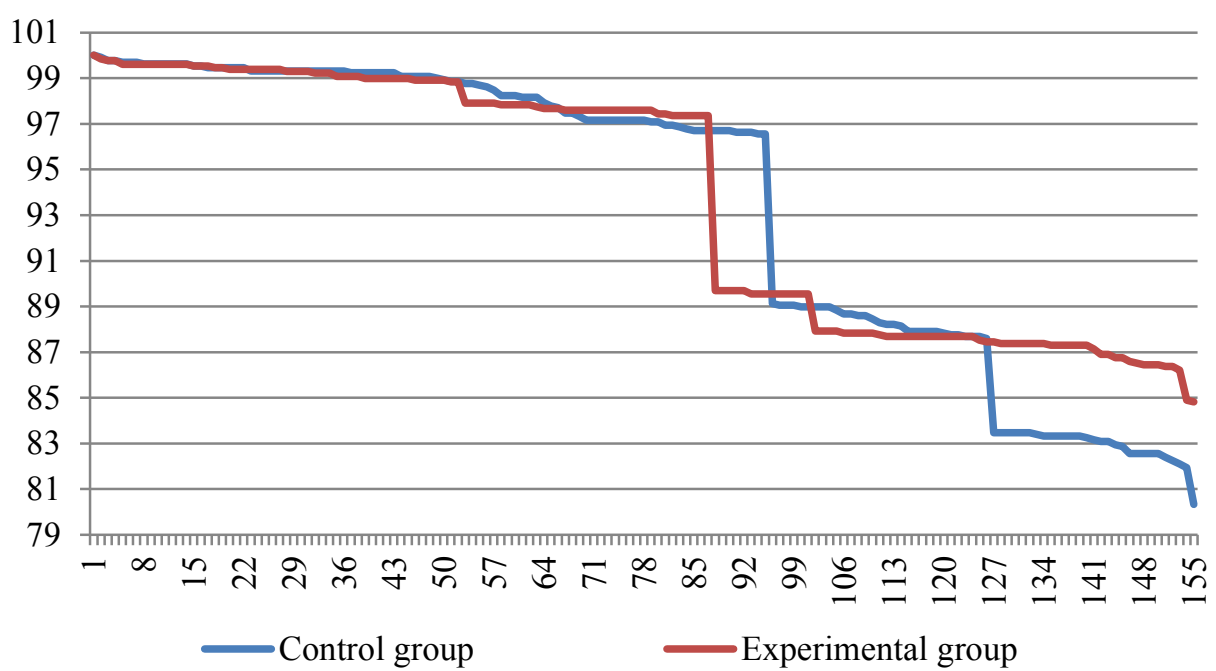

Fig. 2. Crop percent of cockerels by rearing periods, $\%$.

The analysis of Fig. 2 showed that a sharp decrease in the number of cockerels was observed at the age of 13-14 weeks, at 18 weeks (only in control group), and when transferred to the parent flock, which is associated with the culling of young birds. Up to 18 weeks of age, the difference between the control and experimental group in terms of the crop percent of young birds was insignificant (up to $1.1 \%$ ). When transferred to a parent flock, there were $4.5 \%$ more cockerels in the experimental group.

The percentage of disposed birds due to mortality and culling can be seen in Table 6 .

Table 6. Disposal of rearing stock, \%.

\begin{tabular}{|l|c|c|c|c|}
\hline \multirow{2}{*}{ Indicator } & \multicolumn{2}{|c|}{ Control group } & \multicolumn{2}{c|}{ Experimental group } \\
\cline { 2 - 5 } & hens & cockerels & hens & cockerels \\
\hline Mortality during rearing & 3.7 & 7.0 & 1.5 & 3.7 \\
\hline Culling during rearing & 5.4 & 12.7 & 4.3 & 11.4 \\
\hline Total disposal & 9.0 & 19.7 & 5.8 & 15.1 \\
\hline Livability & 91.0 & 80.3 & 94.2 & 84.9 \\
\hline
\end{tabular}

From table 5 it can be concluded that during the rearing period under the influence of chelated forms of trace elements, the mortality of hens and cockerels decreased by $2.2 \%$ and $3.3 \%$, culling decreased by $1.1 \%$ and $1.3 \%$, which contributed to an increase in livability by $3.2 \%$ and $4.6 \%$, respectively.

\section{Conclusions}

Thus, 50\% replacement of inorganic forms of trace elements with organic ones contributed to a more intensive growth of rearing stock of broiler breeders, an increase in the uniformity of the flock, and an increase in livability due to a decrease in the number of dead and culled poultry.

\section{References}

1. Ł. Jarosz, A. Marek, Z. Grądzki, M. Kwiecień, M. Kalinowski, The effect of feed supplementation with zinc chelate and zinc sulphate on selected humoral and cell- 
mediated immune parameters and cytokine concentration in broiler chickens, Research in Veterinary Science, 112 59-65 (2017) https://doi.org/10.1016/j.rvsc.2016.09.007

2. J.Zhao, R.B.Shirley, M.Vazquez-Anon, J.J.Dibner, J.D.Richards, P.Fisher, T.Hampton, K.D.Christensen, J.P.Allard, A.F.Giesen, Effects of chelated trace minerals on growth performance, breast meat yield, and footpad health in commercial meat broilers, Journal of Applied Poultry Research, 1,19, Issue 4 Pages 365-372 (2010) https://doi.org/10.3382/japr.2009-00020

3. B. Owens, M. E. E. McCann, C. Preston The effect of substitution of inorganic zinc with proteinated or chelated zinc on broiler chick performance, Journal of Applied Poultry Research 1, 18, 4, 789-794 (2009) https://doi.org/10.3382/japr.2008-00122

4. G.-B.Kim, Y.M.Seo, K.S.Shin, A.R.Rhee, J.Han, I.K.Paik, Effects of supplemental copper-methionine chelate and copper-soy proteinate on the performance, blood parameters, liver mineral content, and intestinal microflora of broiler chickens, Journal of Applied Poultry Research, 20, 1, 21-32 (2011) https://doi.org/10.3382/japr.2010$\underline{00177}$

5. M. Kwiecień, A. Winiarska-Mieczan, A. Milczarek, E. Tomaszewska, J. Matras, Effects of zinc glycine chelate on growth performance, carcass characteristics, bone quality, and mineral content in bone of broiler chicken, Livestock Science , 191, 43-50 (2016) https://doi.org/10.1016/j.livsci.2016.07.005

6. Ao, T, Pierce J.L., Power R., Pescatore A.J., Cantor A.H., Dawson K.A., Ford M.J., Effects of feeding different forms of zinc and copper on the performance and tissue mineral content of chicks, Poultry Science1, 88, 10, 2171-2175 (2009) https://doi.org/10.3382/ps.2009-00117

7. M. A. Trindade Neto, J. C. Dadalt, M. L. P. Tse, Dietary combination of chelated zinc and threonine and effects on egg production, egg quality and nutrient balance of Brown laying hens from 20 to 49 weeks of age, Animal Feed Science and Technology 267, 114555 (2020) https://doi.org/10.1016/j.anifeedsci.2020.114555

8. C. Xie, H. A. M. Elwan, S. S. Elnesr, X. Y. Dong, X. T. Zou Effect of iron glycine chelate supplementation on egg quality and egg iron enrichment in laying hens, Poultry Science 98, 12, 7101-7109 (2019) https://doi.org/10.3382/ps/pez421

9. Y.N.Min, F.X.Liu, X Qi, S Ji, S.X.Ma,X Liu, Z.P.Wang, Y.P.Gao Effects of methionine hydroxyl analog chelated zinc on laying performance, eggshell quality, eggshell mineral deposition, and activities of Zn-containing enzymes in aged laying hens, Poultry Science, 1 97, 10, 3587-3593 (2018) https://doi.org/10.3382/ps/pey203

10. D. W. Kellogg, E. B. Kegley Encyclopedia of Dairy Sciences, 981-984 (2020) https://doi.org/10.1016/B0-12-227235-8/00367-9

11. Adel Mohammadi, Shokoufe Ghazanfari, Seyed Davood Sharifi, Comparative effects of dietary organic, inorganic, and Nano-selenium complexes and rosemary essential oil on performance, meat quality and selenium deposition in muscles of broiler chickens, Livestock Science, 226, 21-30 (2019) https://doi.org/10.1016/j.livsci.2019.06.001

12. M. K. Manangi, M. Vazques-Añon, J. D. Richards, S. Carter, C. D. Knight The impact of feeding supplemental chelated trace minerals on shell quality, tibia breaking strength, and immune response in laying hens, Journal of Applied Poultry Research, 1 (2015).https://doi.org/10.3382/japr/pfv029

13. M. K. Manangi, M. Vazquez-Añon, J. D. Richards, S. Carter, K. D. Christensen Impact of feeding lower levels of chelated trace minerals versus industry levels of inorganic trace minerals on broiler performance, yield, footpad health, and litter mineral 
concentration, Journal of Applied Poultry Research, 1 (2012) https://doi.org/10.3382/japr.2012-00531

14. J. Zhao, R.B. Shirley, M. Vazquez-Anon, J.J. Dibner, J.D. Richards, P. Fisher, T. Hampton, K.D. Christensen, J.P. Allard, A.F. Giesen Effects of chelated trace minerals on growth performance, breast meat yield, and footpad health in commercial meat broilers, J. Appl. Poult. Res., 19, 365-372 (2010)

15. A.Sh. Kavtarashvili, E.N. Novotorov, T.N. Kolokolnikova, Ways to improve the uniformity of a poultry flock, Poultry and poultry products, 4, 24-27 (2012)

16. A.Sh. Kavtarashvili, E.N. Novotorov, T.N. Kolokolnikova Some techniques for maximizing the uniformity of a poultry flock, Suchasne ptahivnitstvo, 6, 20-23 (2012) 